organisms." Suppose we ask, on the basis of this statement, Why license the one and refuse to license the other?

The point made in favor of lipovaccines in my article was that, using lipovaccines, vaccination can be done at one sitting, whereas three sittings extending over three weeks is required for vaccination when done with saline vaccines. Vaccination at three sittings is possible in military life. In civil life it does not work. In ordinary times for the civilian life, for the uses of municipal and state health departments, the only vaccination worth talking about is one-sitting vaccination.

Now, Dr. Blue may be right as to a laboratory proposition that a saline vaccine containing pneumococci is at least as effective as an oil suspension of the organism; but when it comes to fighting pneumonia and influenza among civilians, he is just about as wrong as a man could be. His action is equivalent to saying that influenza-pnetumonia vaccination shall not be done generally. I do not think this a wise decision.

W. A. Evans, M.D., Chicago.

Comment-CDr. Evans' letter was referred to SurgeonGeneral Blue, who replies: "As Dr. Evans acknowledges the accuracy of my criticisms concerning his citations of the Army use of lipovaccines, and as nothing in that portion of his letter concerning the refusal of the U. S. Public Health Service to license lipovaccines requires any comment in addition to that found in my original letter, no further reply seems to be necessary."-ED.

\section{THE EIGHT HOUR DAY}

To the Editor:-I have translated the following statement from the issuc of La Presse médicale just received. I believe it might well be published in ThE JourNaL.

\section{THE EIGHT HOUR DAY-A FRENCH MEDICAL} INTERPRETATION

" $\mathrm{N}$ o sound comes from the press. In parliament an individual rises and says, "The Labor Party desires an eight hour day.'

"Immediately deputies, senators, they of the left, of the center, of the north, they who follow the red flag and they of the tricolor, all cry with one voice, "Demos has spoken! What he wishes shall be done." "Amen," says Clemenceau. And the law is voted.

"The vote is characteristic of the psychology of modern parlimentarism. Political science, difficult and understood only by economists and by the wise, demands reflection, calculation of the moral and economic consequences which a law will effect and provision in it against counter-strokes and reaction. But politics is no longer the key which opens. enlarged vision nor has politics become more democratic Parliament is democratic and it is charged with the making of laws, but it merely churns them up. Modern parliaments cast laws into the clouds, just as a child might sow seeds, without knowing whether the plants which would arise would be weeds or wheat, a poison or a cure.

"It is impossible to think of a law more inopportune, or one more capable of increasing expenses, diminishing production, paralyzing commerce and industry, and delaying the reconstructions so necessary for our country.

"The ministries and the administrative officers of the state continue to recruit new employees by thousands upon thousands. Evidently this is a clever policy of dealing with the demobilized soldiers without dismissing those who have held office during the war. Evidently the process prevents the advancement of the old employees. The whole is a powerful machine which drains away the labor necessary for the farm and for productive industry.

"One has not yet observed the consequences of this intemperate law. Who would dare to say that before this law was passed there existed any group of overworked laborers in France? On the contrary, rail transportation has become less reliable and more expensive, the ports of the country are tied up, the construction of houses is absolutely at a standstill and indispensable undertakings are postponed until the Greek Kalends.

"For example, the directors of our hospitals are anxiously demanding how they can recruit, pay, lodge and provide food for the additional hundreds of supplementary employees whom the law makes necessary. Are the patients better cared for? No. The chiefs of service must wait for their necessary laboratories; the tuberculous must wait for their sanatoria.

"Unless the popular good sense does not immediately remedy the error of our legislators, we will soon be at the red dawn of a day without bread. For why should a farmer work longer than a hospital attendant? Why should the little guardian of turkeys in the pasture worry over them for longer hours than her sister who is in the beautiful bureau of Monsieur the Minister?

"Oh Parliament, be logical and apply the eight hour day to the workers in the field. Then the citizen will search the market in vain for an ounce of butter or a slice of bacon, even as a young man now will search Paris in vain to find a dwelling place in which to shelter his head and his illusions.

"The demagogue smiles at these miseries. What does he care for the cost of living? If bread fails he will eat cake. Famine may overtake the vulgar, but in ventres dorés there are always truffles."

Grainм Lusk, New York.

\section{Queries and Minor Notes}

Axonymols Commuxicarions and queries on postal cards will not be noticed. Every letter must contain the writer's name and address, but these will be omitted, on request.

\section{HARTMAN STILL WORKING THE PROFESSION}

To the Editor:-The matter I am enclosing looks so much like a "work-the-doctor" game that I thought you might be interested to find out about it. Is it genuine or a collection agency follow-up schemc and is it being worked generally?

I. Z, Frisbie, M.D., Elkland, Pa.

Answer.-The material sent in by Dr. Frisbic was a typewritten letter addressed to "Minister of the Gospel or Town Physician, Elkland, Pa." The letter was signed "Myrtle Moore" and accompanying it was a stamped envelope addressed "Myrtle Moore, 3925 Wentworth Ave., Chicago." The body of the letter was to the effect that Myrtle had recently written to a man (name given) in Elkland, $\mathrm{Pa}$, but her letter had been returned undelivered. This fact led Myrtle to believe that the family had moved without letting her know. Then Myrtle continues:

"If it is not asking too much of yout, I assure you it would be a great favor if you could advise or find out for me without putting yourseli to too much trouble. where a letter can reach this party. It is a matter of considerable importance"

The facts are, there is no Myrtle Moore, 3925 Wentwortl Ave.-for the very good reason that 3925 Wentworth Avenue is a vacant lot. In the adjoining lot, however, 3923 , is the "Administration Building" of the Hartman Furniture and Carpet Company, a concern that sells furniture and house furnishings on the instalment plan. This scheme on the part of the Hartman company to use physicians and ministers of the gospel as unpaid collection agents was exposed editorially in The Journal, August 23, last. At that time we showed that doctors in various parts of the country were receiving letters from "Myrtle Moore," "Helen Taylor" and other more or less hypothetical individuals asking similar questions about the present whereabouts of some individual and enclosing stamped envelops that were addressed to a location in Chicago that did not exist. There is nothin fraudulent about the scheme, as the postal authorities notified us when we took up the matter previously. Nevertheless, it is a cheap and petty piece of unworthy misrepresentation and deceit. It reflects credit neither on the furniture concern that perpetrates it nor the postoffice authorities by whose assistance it becomes effective.

ACRIFLAVINE IN THE TREATMENT OF GONORRHEA

To the Editor:-In The Journal, Nov. 8, 1919, under the heading New and Nonofficial Remedies, I notice a description of acriflavine. I have been told that this was used extensively in France in the treatment of gonorrhea with very good results along the same lines that argyro is employed, that is, an injection in the strength of $1: 1,000$. Please give me more information on this subject, and advise me through whom the drug may be obtained.

$$
\text { C. W. Shackelford, M.D., Fairfield, Ala. }
$$

ANSWER.-A review of the literature on the therapeutic use of acriflavine and proflavine has been prepared by the Council on Pharmacy and Chemistry. The report of the 